\title{
Potential Oil Palm Industry Development
} in Riau*

\author{
Almasdi Syahza, Rosnita, Suwondo, Besri Nasrul \\ Research Institute of the University of Riau
}

* MP3EI research findings in 2013 in Riau Region

\section{ARTICLE INFO \\ Keywords: \\ oil palm industry, \\ regional carrying capacity, \\ Investors}

Corresponding author:

asyahza@yahoo.co.id
A B S T R A C T

Oil palm is one of Indonesia's main commodities that play a role in the growth of the national economy. It has a considerable contribution in generating foreign exchange and employment. Development of Indonesia's CPO processing industry and its derivatives is in line with the growth of plantation area and production of oil palm as a source of raw materials. Until 2011, Indonesia's oil palm plantation area reached 2,103,175 ha with an FFB production of 36,809,252 tons. Meanwhile, oil palm mill (OPM) processing capacity was $30,019,200$ tons only. The analysis showed the regional carrying capacity (RCC) was 1.584. Each FFB should be processed in less than 8 hours or RCC for OPM must be smaller than 1 (RCC, 1). Higher production of oil palm plantations in Riau is the potency to increase the OPM. The results of calculations by land development and farm productivity, Riau region is still lacking of 16 OPM units with a capacity of 60 tons / hour or identical to $21 \mathrm{OPM}$ units at a capacity of 45 tons / hour. The deficiency in OPM impacts the price and income of oil palm farmers in rural areas. High demand for OPM in Riau is a business opportunity for investors to develop an OPM and industry of products derived from oil palm.

(C) 2013 IRJBS, All rights reserved.

\section{INTRODUCTION}

Development of Indonesia's agricultural sector to date is quite rapid, especially the plantation subsector developed in Sumatra and Kalimantan. Specifically for Riau Province, oil palm is a leading commodity that is vastly grown by the people and business entities. Based on data from the Riau Plantation Office (2011), the development of oil palm plantation area increased significantly, from 966,786 ha in 2001 to $2,103,175$ ha in 2011 . During the period 2001-2011, the average growth rate was $8.09 \%$ per year, while other commodities such as rubber and oil declined. Plantation area expansion is followed by an increase in production of fresh fruit bunches (FFB). FFB production amounted to $36,809,252$ tons in 2011 with CPO yields of 6,293,542 tons at an average growth of $13.37 \%$ per year.

Development of oil palm plantations is aimed at addressing poverty and underdevelopment 
especially in rural areas in addition to regarding equality. Plantation-based agricultural development is aimed at improving the welfare of the people so that there is a change in the lifestyle of the people around it. From the side of agribusiness-based plantation, oil palm is expected to reduce income inequality among social groups and among regions.

The oil palm plantation activities are supported by 146 units of oil palm mill (OPM) scattered unevenly (centered in the nucleus and plasma plantations) in various districts / cities in Riau Province. The distance of independent farmers' land from the existing OPMs leads to low quality of FFB in the mill due to the large distance between the plantations and OPMs.

Agribusiness of oil palm plantations in Riau is evolving so rapidly, but not matched by the development of FFB processing industry construction called OPM. Lack of OPM processing capacity leads to accumulation of raw materials in the plantation sites. FFB price at the farmer level (independent farmers) is highly determined by collectors at the village level, while farmers who are involved with plasma activities (which are fostered by the foster father) get the priority of FFB processing, because FFB of the farmers is purchased by cooperatives run by a foster father (core company).

From the foregoing, in this study the authors propose the problem statement as a starting point for the study, namely: 1) How big is the regional carrying capacity (RCC) to the development of oil palm downstream industry? 2) Is the development of downstream oil palm industry can open up employment opportunities and business opportunities in Riau region? Based on the issues raised, the purpose of this research is that the research findings can be a reference for policy makers and oil palm-based agribusiness. The research findings are expected to provide information such as: 1) the regional carrying capacity (RCC) to the development of downstream oil palm industry, 2) the potential development of downstream oil palm industry in an effort to improve the welfare of the people through employment opportunities and business opportunities in the region.

The merit of this research is the coverage of development areas of downstream oil palm industry in an effort to spur economic growth in rural areas through the development of products derived from oil palm. The development strategy is aimed at creating economic added value so that efforts to accelerate economic development can be improved.

The research findings are useful for agribusiness actors and governments as business decisionmakers with respect to the development of oil palm plantations. It is expected that improvements resulting in increased added value to oil palm agribusiness actors, particularly smallholder (plasma) and independent farmers (local community) so as to improve the welfare of the community. Findings of the research conducted can provide strategic formulation to utilize local resources through the development of oil palm plantations and its derivatives.

\section{Theoretical Framework}

From the research findings of Almasdi Syahza (2005), the development of oil palm plantations in Riau gave double impacts on the region's economy, particularly in creating employment and business opportunities. The development has provided a trickle-down effect, so as to expand the power of dispersion to the surrounding community. The larger the development, the higher impact affects workers who work in the plantation sector and its derivatives. The effect can be seen from the increase in farmers' incomes that increase the purchasing power of the rural communities, for both primary and secondary needs.

The impacts on the community around the 
development of oil palm plantations are reflected in the creation of employment and business opportunities for the local community, such as opening up businesses of food and beverage kiosks, transportation services, home industries, as well as banking services. The resulting impacts cause the emergence of traditional markets in residential and rural areas, thus increasing the level of incomes and social welfare, which affects an increasing pattern of public consumption and education (Almasdi Syahza, 2007a).

Oil palm plantation development activities, which involve a lot of labor and a relatively large investment for the downstream industry, are expected to grow and create employment and business opportunities. Through the economic activities that produce goods and services required during the course, the development of oil palm plantations and the downstream industry will have backward linkages. In the course of these activities, it is expected to appear among others construction services, farm labor services, transportation services, food and clothing trade, working tools trade as well as stuff and materials required during the process. Meanwhile, the postharvest activities and production processes will have forward linkages. The process of forward linkages that is likely to arise is the service sector includes transportation, hospitality, cooperatives, banking, and trading (Almasdi Syahza, 2007b). Actually, Riau region has a great potency to develop products derived from oil palm (downstream industry). The oil palm downstream industry in the future may become a strategic and prioritized leading commodity of plantations (Riau Terkini, 2006). However, the downstream industry to date has not been materialized.

Development of plantations in rural areas has opened up job opportunities for people who are able to accept these opportunities. With the plantation companies, local community livelihoods are no longer limited to the primary sector, but they have expanded the space to the tertiary sector. A range of contributing sources of income include traders (trading of daily needs, rubber, transportation ticket and vending ice), employees (teachers, village administrators), domestic industry (tofu, bread, and tile casting industries), unskilled laborers, fishermen, woodcutters in the forest and carpenters (Almasdi Syahza, 2009a).

For people in rural areas, to date plantation business is an alternative to changing their household economic condition, because the public interest to plantation development is still high. Oil palm agribusiness shows an increase in the welfare of rural farmers. Plantation development activities have led to the high mobility of the population. According Soemarwoto Otto (2001), population growth tends to lead to smaller land area, which leads to increasing population pressure on land. Furthermore, in shifting cultivation area, increased population density also increases population pressure on land due to the rising needs for food, which consequently shorten the grace period of land. Furthermore, Mustari and Mapangaja (2005) state that in the increasing density of population, the carrying capacity of land will eventually be exceeded. This indicates that land in an area can no longer support the population at a certain level of welfare.

From the research findings of Almasdi Syahza (2010), the development of oil palm plantations in Riau have an impact on rural economic activities, in which farmers' incomes ranged from US\$ $4,633.37$ to $\$$ US 5,500.32 per year. Moreover, it also has an impact on the acceleration of economic development in an effort to alleviate rural poverty. The impact of these activities is seen from the indicators: 1) oil palm cultivation to reduce income inequality in rural areas; 2) population pressure without plantation subsector exceeding land capacity (>1), which is equal to 6.01 in 2004 to increase to 11.04 in 2008; 3) very high land carrying capacity (LCC) of Riau region, amounting to 129.3 in 2004 and increasing to 138.77 in 2008 ; 4) increased number of residents within the 
geographical boundaries having led to severe pressure on available land resources; 5 ) increased money supply in the rural areas, which requires the need for the establishment of institutions that deals with the community needs; 6) provision of external influences that are positive or beneficial to the surrounding areas; the benefits to the socioeconomic aspects include an increase in the welfare of the surrounding community, expansion of employment and business opportunities, and contribution to regional development; 7) Some oil palm plantation activities that directly impact the socio-economic and cultural components of the surrounding communities, among others: a) employment of the local workforce, b) rural community development activities; c) development of infrastructure that can be utilized by the local community, especially land road; d) extension on agriculture, health and education; and e) payment of the company's obligations to the state (taxes and other compensation costs); and 8) development of oil palm plantations in Riau region can reduce income inequality among rural groups. Oil palm development can also reduce the level of inequality among districts / cities in Riau.

The rapid development of oil palm plantations causes the establishment of rural economic growth centers around the plantation development areas. This condition subsequently causes the increasing purchasing power of rural people, especially to their daily needs of household and production facilities of oil palm plantations. From the other side, plantings will require land; if it is not controlled by policy-makers, conversion of land in rural areas will happen.

Development of oil palm plantations in Riau has reduced income inequality among rural groups (Almasdi Syahza, 2012). Plantation activities led people's livelihood to be no longer limited to the primary sector in meeting the needs of their families, but have expanded their business space in the tertiary sector (Almasdi Syahza, 2006). Oil palm plantation is one of the programs that succeed in empowering rural communities (Almasdi Syahza, 2007b). In an effort to spur economic growth and improve the economic multiplier effect, it is necessary to develop an oil palm-based agroestate concept (Almasdi Syahza, 2005). Oil palm cultivation has contributed to the development economic institutions in rural areas (Almasdi Syahza, 2008). Oil palm has an impact on the acceleration of economic growth in rural areas (Almasdi Syahza, 2009b, 2010, and 2011).

Powerlessness of rural communities is among others due to the mismatch of past policies, which did not consider the agricultural sector as a basis for comparative and competitive advantages. Indeed, the economic empowerment of rural communities is not only beneficial for rural people themselves, but also to build Indonesia's economic strength based on the comparative and competitive advantages possessed (Yuswar Zainal Basri, 2003).

Income inequality between rural and urban areas is quite high; thus, agribusiness is a solution to reduce inequality. According to Lewis in Todaro, Michael P. (2006), underdeveloped economy consists of two sectors: 1) traditional sector, the subsistence rural sector which is overpopulation and characterized by the marginal productivity of labor is zero; 2) the modern urban industrial sector which has a high level of productivity and becomes a labor shelter to be transferred gradually from the subsistence sector. Lewis assumes that wage rates in urban areas are 30 percent higher than the average income in rural areas. This condition forces workers to move from villages to cities.

Rural development should be able to reduce the gap between rural and urban areas. One of the concepts ever raised by Friedmann J. and Mike Douglass in Almasdi Syahza (2007b) is agropolitan development. The concept presents how to accelerate rural development with potencies possessed by the village. Therefore, what needs to be addressed: first, changing rural areas by 
introducing elements of city lifestyle (urbanism) which is adjusted to certain rural environment. This form does no longer encourage rural-urban migration. Investment in rural areas is one way of pressing urbanization and changing rural settlements into a mixed form called Agropolis or city in agricultural fields; second, expanding social relations of rural areas beyond the village boundaries, so a wider socio-economic and political space (agropolitan district) will be established; third, minimizing social dislocation in the development process, namely: maintaining family unity, strengthening sense of security, and providing personal satisfaction in building a new society; fourth, stabilizing rural and urban revenue. Minimizing the difference by achieving productive employment opportunities in rural areas, in particular integrating agricultural with nonagricultural activities in the same environment; fifth, using the existing workforce more effectively by directing to the resource development efforts in each agropolitan district, including increasing agricultural products; sixth, stringing up agropolitan district into a regional network by way of building and improving relations between agropolitan district and city; seventh, arranging a government and a plan that suits the environment so it can control the priority on development and the implementation to local residents; eighth, providing financial resources to build agropolitan.

According to Gina Kartasasmita (1996), rural development must be done in accordance with an approach as per the nature and characteristics. Rural development should follow the four great efforts, which are inter-related to each other and a central strategy for rural development, namely: first, economic empowerment of rural communities. In this effort necessary, capital inflow and guidance on the use of technology and marketing to enable and empower villagers are required; second, improving the quality of rural human resources in order to have a reasonable basis to improve and strengthen productivity and competitiveness; third, development of rural infrastructure. For rural areas, transportation infrastructure is an absolute necessity because transportation infrastructure will spur rural communities from underdevelopment; and fourth, building rural institutions both formal and informal. Rural institutions required are the creation of good services, especially to boost the rural economy, such as financial institutions.

For the Indonesian government, rural development has been referred to the development of the agricultural sector, which is then developed in the form of agribusiness. The current agricultural development that is developed in a large-scale form is plantation sub-sector, which becomes leading exported commodities, among others, oil palm, rubber, uncaria, coconut. Bustanul Arifin (2001) states the development of agricultural sector in the broad sense should be directed to agribusiness and agro-industry system because this approach will be able to increase agricultural added value, which can substantially increase incomes of local agribusiness and agro-industry actors.

The role of agribusiness in Indonesia's economy is highly important, and even the degree of its importance is expected to increase, especially after the mining industry and oil production decline to an extremely worrying level. Agribusiness sector mobilization requires cooperation of various shareholders, including the government, private sector, farmers, and banking, thus, this sector is able to contribute to national revenue. Policies in terms of investment increase should be supported by the creation of a favorable investment climate in Indonesia, including bureaucracy, access to credit, and a review of tax regulations and tax rates for the agribusiness sector (Gumbira Sa'id, E. and L. Febriyanti, 2005).

The development of agricultural sector in the broad sense should be directed to agribusiness and agro-industry system because this approach will be able to increase agricultural added value, which can substantially increase incomes of local agribusiness and agro-industry actors. As per the 
research findings of Almasdi Syahza (2005), other factors supporting agribusiness development prospects for the future include: 1) growing population that increases food demand as well; this is a good market opportunity for agribusiness; 2) rising incomes of the people that will improve the quality and diversification of food needs. Product diversity requires yield processing (agroindustry), and 3) the development of agribusiness that will also have an impact on economic growth of a region, increase farmers' income, and in turn is expected to reduce income inequality.

In the future development of the agricultural sector, some obstacles are encountered, especially in the development of agribusiness and agroindustry-based agricultural systems. Obstacles encountered in the development of agriculture, especially for small-scale farmers, include (Almasdi Syahza, 2007A): 1) weak capital structure and access to capital sources, 2), availability of land and soil fertility problems, 3) procurement and distribution of production facilities, 4) limited ability in mastering the technology, 5) lack of organization and management of agribusiness, and 6) lack of quantity and quality of human resources for the agribusiness sector. Farmers are the human resources who play an important role in determining the success of agribusiness activities, because farmers are the workers and also the managers of the agribusiness activities.

\section{METHODS}

The research was conducted through a survey using the developmental method (developmental research). The developmental research aims to investigate the pattern and order of growth or changes as a function of time. The research sites are areas that are potential for development of oil palm plantations, either through state-owned enterprises (SOEs) and private-owned companies (POEs) or independently by the community. The research sites would be divided into two parts, mainland and coastal areas. The Riau mainland areas include Kampar District, Rokan Hulu District, and Kuantan Singingi District, while Riau coastal areas include Pelalawan, Siak, Bengkalis, Indragiri Hilir, Indragiri Hulu and Rokan Hilir. Both research sites have different productivity due to differences in soil fertility.

The data required are the primary and secondary data. The secondary data were obtained from relevant authorities and from oil palm companies. The information required forms policies by local governments and plantation companies. Primary data were collected using a questionnaire developed based on the research needs. To get accurate information, the Rapid Rural Appraisal (RRA), which is a participatory approach to get general data / information and assessment in the field in a relatively short time, was conducted. In this RRA method, the information collected was limited to information required for the research purposes, but it was done more deeply to explore information resources to obtain complete information about a certain thing.

To get the research findings in order to obtain accurate information on potential economic development of oil palm through development of oil palm-based downstream industry, it is necessary to do some analysis, among others: 1) regional carrying capacity (RCC);2) potential development of oil palm downstream industry; and 3) employment opportunities and business opportunities in the study area; 4) coverage of production centers and development areas of oil palm-based downstream industry on potential areas.

Analysis of the regional carrying capacity (RCC) was conducted to determine the ability of Riau in providing raw materials for the oil palm industry (FFB). To determine the RCC, the oil palm production data and the amount of raw material requirement for downstream oil palm industry (OPM) were used. Mathematically, the regional carrying capacity to the oil palm industry shall be as follows: 
DDDW $=\frac{\mathrm{L}_{\mathrm{i}} \times \mathrm{P}_{\mathrm{i}}}{\mathrm{KBB}}$

Description: $\mathrm{RCC}$ is the regional carrying capacity in the development of downstream oil palm industry, $A_{i}$ is the total area of oil palm plantations in Riau, $P_{i}$ is productivity per hectare of oil palm plantations, and RMR is the raw material requirement of the oil palm industry in the form of FFB.

If the calculation shows the ratio $>1$, the regional carrying capacity in the development of oil palm downstream industry is quite strong, and vice versa if the ratio is $<1$, the regional carrying capacity is very weak.

To estimate the OPM production capacity required, use the following assumptions: 1) the plants operating 20 hours per day, 2) in one calendar month working for 25 days; 3) FFB production based on data in 2011 ; 4) plantation optimum production assumed to be 22.8 tons / ha / year; and 5) OPM capacity of 60 tons / hour. The data on indicators required is oil palm feedstock availability in the region. Based on the data on indicators and assumptions mentioned above, the future requirement of OPM can be projected. OPM capacity requirement to cultivate FFB can be calculated by the following formula:

$\mathrm{TKP}=\frac{\mathrm{TM} \times \mathrm{Pr}}{\mathrm{JK} \times \mathrm{JH} \times 12}$

Description: TPC is total plant capacity; PC is area of mature crops; Pr is productivity of land per year; WH is plant working hours per day, and WD is total plant working days per month.

\section{RESULTS AND DISCUSSION}

\section{A. Development of CPO Industry}

Indonesia's crude palm oil (CPO) industry continues to grow rapidly from year to year. CPO production increased to 21.0 million tons in 2010 from 19.4 million tons of the previous year. In 2011 , the production was expected to rise $4.7 \%$ to about 22.0 million tons. Meanwhile, total exports also increased, which was recorded at 15.65 million tons in 2010 , and was expected to rise to 18.0 million tons in 2011. Until now Indonesia still occupies the top position of the world's biggest crude palm oil producer, with an output of 21.8 million tons in 2010. Of the total production, it is estimated that only about $25 \%$, or 5.45 million tons, is consumed by the domestic market. As the world's largest crude palm oil producer, Indonesia continues to develop new export markets to market its products and expand the existing markets, for example, Pakistan, Bangladesh, and Eastern Europe and China.

The increase in CPO production was supported by the growing total area of oil palm plantations to 7.9 million hectares in 2011 from 7.5 million hectares in 2010. Currently, the government sets infrastructure improvements in all existing $\mathrm{CPO}$ land in Indonesia, including the five basic clusters that have been prepared by the government, namely North Coast of Java, East Coast of Sumatra, East Kalimantan, Sulawesi and Merauke.

Nonetheless, to date, Indonesia as the world's largest crude palm oil producer still gets the smallest value of palm oil production because most palm oil is exported in crude palm oil (CPO) or in simple processed products, such as cooking oil, whereas the added value of CPO downstream industry is very large.

Given that the role of palm oil in the world's supply of oil consumption grows bigger, the market opportunity for $\mathrm{CPO}$ and processed products is getting bigger as well. Similarly, the potency for Indonesia to be a $\mathrm{CPO}$ producer remains large because it is still supported by the availability of land for development. However, efforts to obtain greater value from palm oil, not only by exporting $\mathrm{CPO}$, are required.

CPO processing industry development efforts could not simply operate without government 
support because the current demands of the market makes it more profitable to export $\mathrm{CPO}$ than to process it in the country. In addition, CPObased industry in Indonesia has not fully integrated the upstream and downstream industries. High potential raw material should be used for the development of downstream industry, because it has a high added value and leads to a highly significant multiplier effect.

In terms of geography and employment, Indonesia has an advantage for potential development of oil palm plantations and CPO industry. In terms of raw material competitiveness, Indonesia has a high availability of raw materials given the most extensive nationwide oil palm plantations in the world. On the other hand, Malaysia is expected to come to a saturation point due to the narrow land. The planned expansion of Indonesia's oil palm plantations is expected to boost Indonesia's role in the world's oil palm sector. On the other hand, Malaysia, as the second CPO producer in the world, no longer has new development land, in which case it only has an increase in productivity at an average of $3 \%$.

Development of oil palm derivatives in the future has a very good prospect. In the framework of its development, support from all stakeholders from cultivation, production and marketing processes is required. These efforts need to be supported by relevant agencies such as $R \& D, H R$, machinery and equipment providers as well as banking / capital institutions. Therefore, in order to realize the efforts to increase the production and exports of $\mathrm{CPO}$ derivative products in type, volume and value of exports through the development of CPO downstream industry and to fill the void in production capacity of existing downstream industry will need to establish a roadmap of CPO industrial cluster development.

Utilization of CPO for processed products includes food industry and non-food industries. The food industry includes cooking oil, margarine, shortening, cocoa butter substitutes, and vegetable ghee, while non-food industries include oleochemicals (fatty acid, fatty alcohol, glycerin) and biodiesel. Until now there are about 23 types of derivative products that have been manufactured in Indonesia. The core industries, supporting industries and related industries of CPO include:

1) The core industries that have developed are CPO industry and palm kernel oil (PKO) industry;

2) Related Industries that have begun to develop include CPO derivatives: Stearine, RBD PO, RBD Palm Olein, Margarine, Shortening, RBD Palm Stearine, CBS / CBE, Creaming Fats, Vegetable Ghee. Similarly, related industries of palm kernel include Fatty Alcohol and Fatty Acid.

3) Related Industries that have not developed include Palm Kernel Cake, Crude Palm Fatty Acid, RBD Palm Kernel Stearin, Metallic Salt, Polyethoxylated Derivatives, Fatty Amines, Fatty Amide, Soaps, Animal Feed, Glycerol, and Glycerin.

4) Supporting Industries that have developed include OPM equipment machinery industry, palm cooking oil equipment machinery industry, storage tank, piping, packaging industry, Oil Palm Research Center.

5) Supporting Industries that have not developed include $\mathrm{CPO}$ derivative equipment machinery industry, fine chemicals industry, acid phosphate industry, breeding industry, research institutions, and so forth.

\section{Upstream Industry Group}

Oil palm is one of Indonesia's main commodities that play a role in the growth of the national economy, with a substantial contribution in generating foreign exchange and employment. Development of processing industry of CPO and its derivatives in Indonesia is consistent with the growth of plantation area and oil palm production as a source of raw material. 
Oil palm plantations produce fresh fruit bunches (upstream), which are then processed into crude palm oil (downstream for oil palm plantation and upstream for CPO-based industries). In addition to producing crude palm oil products, processing of fresh fruit bunches (FFB) also produce PKO (palm kernel oil). PKO production increases in line with the increase in CPO products, which is about $20 \%$ of $\mathrm{CPO}$ produced.

\section{Between Industry Group}

From crude oil palm (CPO) and palm kernel oil (PKO) can be produced in various kinds of oil palm intermediate products used as feedstock for downstream industries for both food and non-food categories. The oil palm intermediate industry group includes industry olein, stearin, and basic oleochemicals (fatty acid, fatty alcohol, fatty amines, methyl ester, glycerol) industries.

\section{Downstream Industry Group}

From the oil palm intermediate products various kinds of products can be produced, most of which are products that have potential market shares, for both domestic market shares and export market shares. Development of the oil palm downstream industry needs to be done considering the high added value of oil palm downstream products. Types of oil palm downstream industry are very broad in terms of spectrum, up to more than 100 downstream products that can be produced on an industrial scale. However, only about 23 types of downstream (food and non-food) products commercially produced in Indonesia.

Several downstream derivative products of $\mathrm{CPO}$ and PKO produced for food categories include: cooking oil, salad oil, shortening, margarine, Cocoa Butter Substitute (CBS), vanaspati, vegetable ghee, food emulsifiers, fat powder, and ice cream. Meanwhile, non-food categories include: surfactants, biodiesel and other oleochemical derivatives

Rated capacity of the world's basic oleochemical industry is much larger than the world's oleochemical needs. However, world's demand for oleochemical products continues to increase from year to year. The increase in demand for the world's oleochemical has an average rate of about $5 \%$ per year.

\section{B. Regional Carrying Capacity (RCC) to Oil Palm Downstream Industry Development}

The high interest of rural communities in Riau to oil palm cultivation has made Riau the largest oil palm producer in Indonesia. Oil palm plantation area based on data in 2011 has reached 2,085,068 ha (not including damaged crops) and production of fresh fruit bunches (FFB) of 36,809,252 tons per year with productivity of 22.8 tons per hectare per year. Based on the land condition and soil fertility in Riau, the CPO productivity is 3.9 tons per hectare per year. Meanwhile, the number of oil palm mills in Riau is 146 units with a production capacity of 6,245 tons per hour spread over several districts. FFB and CPO production distribution and spread of OPM with the capacity is presented in Table 1 .

From the high people's desire to have oil palm plantation, the oil palm plantation area in the future is predicted to be always increasing. The increasing area will be followed by an increase in FFB production. This condition will also cause the FFB processing capacity to be increasingly needed, in terms of quantity and capacity of processed products. Similarly, for the existing area, production will increase because there are many immature crops. Until 2011 the planted area of immature crops was 470,713 ha spread in twelve districts / cities.

The rapid development of oil palm cultivation is due to a chance to change their fate. Development of oil palm plantations has been able to give high contribution to the household incomes. Oil palm cultivation activities have been able to create a multiplier effect in the rural economy. The money supply increases, the purchasing power of the rural community increases, and the demand for 
Table 1. Production of FFB, CPO, Oil Palm Land Productivity and OPM Capacity in Riau in 2011

\begin{tabular}{rlrrrr}
\hline & District / City & $\begin{array}{c}\text { FFB Production } \\
\text { (ton/year) }\end{array}$ & $\begin{array}{c}\text { Production } \\
\text { (CPO ton) }\end{array}$ & \multicolumn{2}{c}{ OPM/Capacity } \\
\cline { 5 - 6 } 1 & Kampar & $7,680,797$ & $1,273,944$ & 35 & Ton/hour \\
2 & Rokan Hulu & $6,150,819$ & 989,041 & 22 & 975 \\
3 & Pelalawan & $3,737,648$ & 648,197 & 17 & 715 \\
4 & Indragiri Hulu & $2,185,196$ & 389,113 & 8 & 285 \\
5 & Kuantan Singingi & $2,392,285$ & 431,385 & 10 & 450 \\
6 & Bengkalis & $2,303,132$ & 435,688 & 8 & 350 \\
7 & Rokan Hilir & $4,639,402$ & 797,644 & 22 & 915 \\
8 & Dumai & 406,727 & 75,085 & 1 & 60 \\
9 & Siak & $4,035,206$ & 704,027 & 15 & 685 \\
10 & Indragiri Hilir & $3,097,067$ & 518,911 & 8 & 385 \\
11 & Pekanbaru & 180,973 & 30,507 & - & - \\
12 & Meranti Island & & & - & 6,245 \\
\hline Total & & $36,809,252$ & $6,293,542$ & 146 & \\
\hline Land Productivity & 22.80 & 3.90 & & \\
\hline
\end{tabular}

Source: Riau Plantation Office, 2012

goods also increases. As a result, mobility of goods and people among villages and cities occurs. The impact of all these will continue to increase in oil palm cultivation.

Development of oil palm cultivation gives impact on increased oil palm plantation yield of FFB. From the other side, the development of processing plant construction is not comparable to the development of community plantation production. It causes accumulated plantation yield (FFB), either around the community plantations or in OPMs. This condition is felt to non-smallholder farmers (independent farmers). Even, harvested FFB is often late to be purchased by collectors or processed by OPM. The late processing will affect the quality of FFB itself because it can increase fatty acid content. Development and high public interest to the oil palm cultivation has led to excess raw material of OPMs, because OPMs are not able to accommodate FFB, which is excessive in production. As a result, the comparison between land production and availability of OPM is not balanced (RCC greater than 1). Thus, an analysis of regional carrying capacity (RCC) in the supply of OPM raw materials is required.

Analysis results of RCC calculation of oil palm industry are presented in Table 2 . The calculation results are based on the assumption of availability of indicators, among others: productive land area, for both mature and immature crops, land productivity, and rated capacity. Based on this assumption, RCC index obtained is 1,226 (OPM operating hours of 400 hours per month and for 25 working days per month). The calculation results prove that RCC figure is greater than 1, which means the regional carrying capacity of Riau to supply of OPM raw materials is considerably large. For each unit of OPM processing capacity is supported by FFB raw materials of 1,226 units. If it is assumed that OPM operation is 500 hours per month (20 hours per day for 25 days per month) the $\mathrm{RCC}$ is 0,981 . It means that the rated capacity of machine is sufficient for processing of FFB raw materials. However, on the other side, from the 


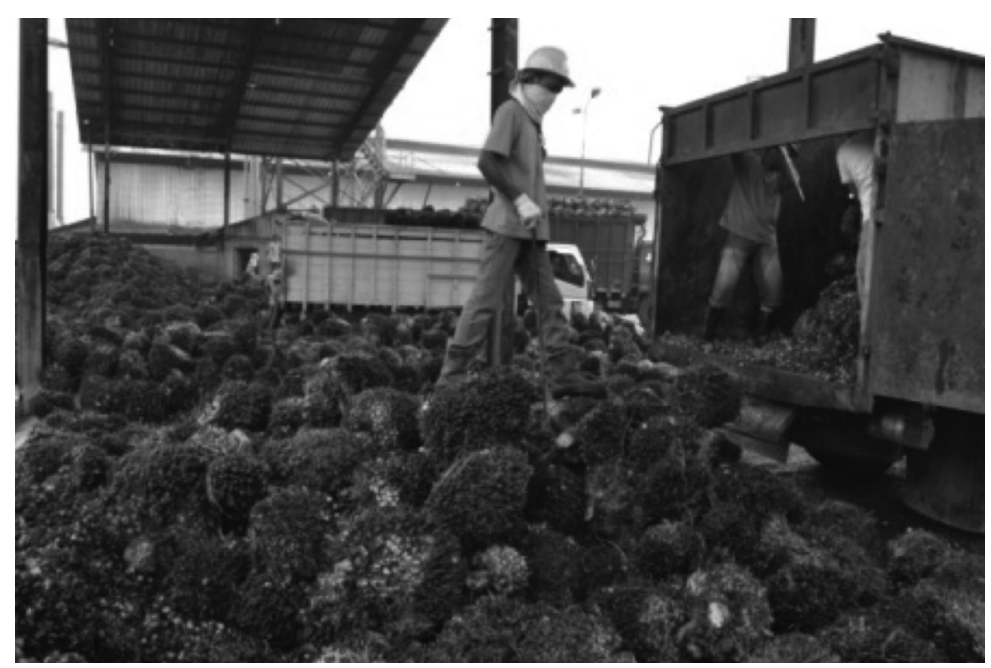

Picture 1. Process of sorting FFB in one of oil palm mill in Riau

reality on the ground there are FFBs that are late to be processed, which is primarily caused by nonevenly distributed OPM and plantation locations are as per the processing capacity of OPM.

For the future, FFB production will increase because there are plantations with immature crops. Assuming that all plantations of both immature plants (TBM) and mature plants (TM) are in production, the RCC will increase to 1,584. The calculation assumes OPM working hours of 400 hours per month. Assuming that the OPM working hours per month are 500 hours (20 hours per day, 25 days per month), the RCC will be 1.267. This figure also shows that the raw materials for OPM remain in excess. For more details, RCC each county / city are presented in Table 2 .

For information, in the provisions, FFB must be processed within 8 hours after harvest. If FFB is not processed in time, the free fatty acid content will increase and this causes FFB quality to be degraded after arriving at OPM. This will result in a decrease in selling prices by farmers. To maintain the quality of FFB, each FFB arriving at OPM should be immediately processed. It means that RCC must not be greater than $1(\mathrm{RCC}<1)$. When it can be met, the quality of FFB and free fatty acid content can be tolerated, and the content of CPO can be improved.
The high number of RCC shows the abundance of raw materials available in the Riau region. Excess raw materials will lead to inefficient production processes. Excess raw materials supplied from the farmers would cause a decrease in the selling price of farmers. Because the market condition faced by the farmers is monopsonistic, the farmers have no bargaining power, so that they simply accept the price from the merchant (OPM accomplice). This condition also makes FFB prices at farmer level fluctuate greatly, especially for purely independent farmers.

Based on the calculation results using the available data, Riau region is still lack of OPM for the future. This prediction is based on the existing oil palm plantation area that trends to grow and the extent of immature plants. Thus, in the future the development of oil palm mill (OPM) is still needed. For consideration, the prediction for future OPM in Riau is presented in Table 3.

\section{MANAGERIAL IMPLICATIONS}

Crude oil palm products have quite high forward linkages and backward linkages. Crude oil palm downstream industry is very strategic and concerns with the livelihood of the people, such as cooking oil industry. The government should pay high attention to the structure of the domestic cooking oil market. Most Indonesian people still expect the 
Table 2. OPM Deployment and Calculation Results of Regional Carrying Capacity (RCC) to Oil Palm Industry in Riau in 2012

\begin{tabular}{|c|c|c|c|c|c|c|c|}
\hline \multicolumn{2}{|r|}{ District / City } & \multicolumn{3}{|c|}{ Land Area (in 2011) } & \multicolumn{2}{|c|}{ OPM/ Capacity } & \multirow[t]{2}{*}{$\mathrm{RCC}$} \\
\hline & & $\mathrm{MC}$ & IMC & Total & Unit & Ton hour & \\
\hline 1 & Kampar & 320,466 & 33,262 & 353,728 & 35 & 1.425 & 1.123 \\
\hline 2 & Rokan Hulu & 254,680 & 161,756 & 416,436 & 22 & 975 & 1.302 \\
\hline 3 & Pelalawan & 161,235 & 21,600 & 182,835 & 17 & 715 & 1.089 \\
\hline 4 & Indragiri Hulu & 98,222 & 19,993 & 118,215 & 8 & 285 & 1.597 \\
\hline 5 & Kuantan Singingi & 105,382 & 16,189 & 121,571 & 10 & 450 & 1.108 \\
\hline 6 & Bengkalis & 108,247 & 62,619 & 170,866 & 8 & 350 & 1.371 \\
\hline 7 & Rokan Hilir & 216,134 & 19,602 & 235,736 & 22 & 915 & 1.056 \\
\hline 8 & Dumai & 20,135 & 12,281 & 32,416 & 1 & 60 & 1.412 \\
\hline 9 & Siak & 182,660 & 50,048 & 232,708 & 15 & 685 & 1.227 \\
\hline 10 & Indragiri Hilir & 139,696 & 72,781 & 212,477 & 8 & 385 & 1.676 \\
\hline 11 & Pekanbaru & 7,498 & 582 & 8,080 & - & - & \\
\hline 12 & Meranti Islands & - & - & - & & & \\
\hline Total & & $1,614,355$ & 470,713 & $2,085,068$ & 146 & 6,245 & 1.226 \\
\hline \multicolumn{7}{|c|}{ Working hours are 500 hours / month (20 hours / day), 25 days / month } & 0.981 \\
\hline \multicolumn{7}{|c|}{ Including IMC, if the working hours are 400 hours / month } & 1.584 \\
\hline \multicolumn{7}{|c|}{ Including IMC, if the working hours are 500 hours / month } & 1.267 \\
\hline
\end{tabular}

Table 3. Predicted Need of Oil Palm Processing Plants in Riau

\begin{tabular}{lr}
\hline \multicolumn{1}{c}{ Estimated Indicator } & Quantity \\
\hline Total Area (ha) in 2011 & $2,085,068$ \\
\hline FFB production (tons) in 2011 & $36,809,252$ \\
\hline Existing OPM (units) & 146 \\
\hline OPM rated capacity (tons / hour) & 6,245 \\
\hline Projected Need of OPM & $2,085,068$ \\
\hline Existing land area (ha) in 2011 & $36,809,252$ \\
\hline Production (tons of FFB) in 2011 & 6,254 \\
\hline OPM rated capacity (tons of FFB / hour) & $30,019,200$ \\
\hline Processing capacity (tons of FFB / year) in 2011 & $6,790,052$ \\
\hline Excess raw materials (tons of FFB) & 16 \\
\hline OPM deficiency (60 tons FFB / hour) $^{1}$ & 19 \\
\hline OPM deficiency (60 tons FFB / hour) $^{2}$ & $30,019,200$ \\
\hline Prediction if IC and IMC are calculated & $17,522,309$ \\
\hline Processing capacity of OPM & 41 \\
\hline Not processed (productivity 22.8 tons / year) & \\
\hline OPM deficiency (60 tons of FFB / hour) $^{1}$ & \\
\hline Note: & \\
\hline
\end{tabular}

1) working hours are 600 hours / month, 25 days / month

2) working hours are 500 hours / month, 25 days / month 


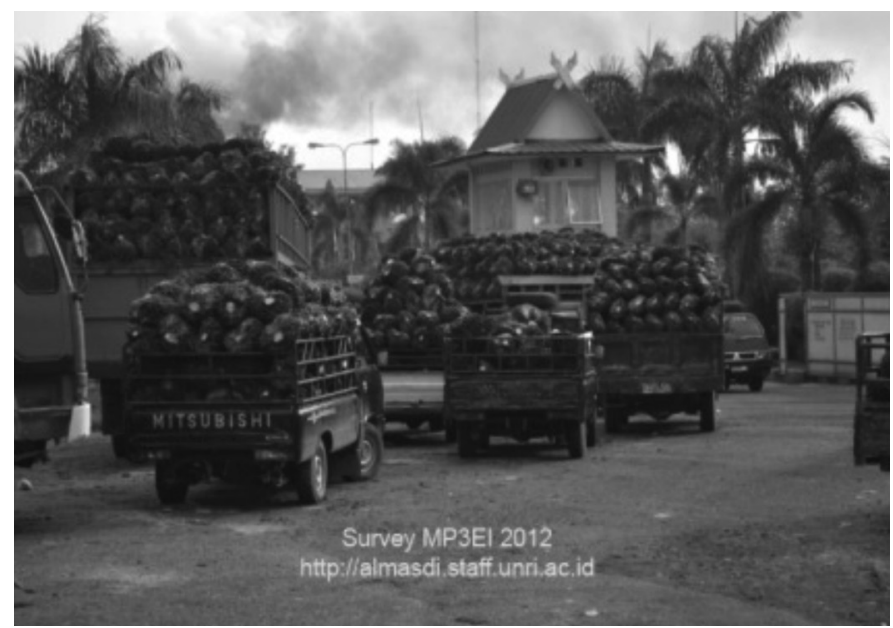

Picture 2. FFB truck queue in one of the mills in Riau

availability of sufficient cooking oil as part of food security. However, a series of government policies is still too focused on $\mathrm{CPO}$ and forgets about a set of problems in the structure of downstream industry, i.e. cooking oil.

Oil palm commodity, which began in 1980 in Riau Province, has progressed quite rapidly. Until 2011, Riau has a total plantation area of 2,085,068 ha (not including damaged crops) with the production of crude palm oil (CPO) of 6,293,542 tons per year. Realization of CPO exports reached 6.1 million tons. Development of oil palm processing industry up to the level of CPO and PKO reached 146 units with a capacity of 6,254 tons per hour, while in the downstream industry there is only one unit of refinery, one unit of cooking oil mill and three units of biodiesel plant and the figures continue to grow. The great potency of CPO when processed into food and energy will certainly provide greater added value for farmers' welfare and quality of life in Riau Province.

The prospect for oil palm agro-industry development in Riau region is still highly bright. To achieve this, there are several steps that need to be done. First, increasing the land productivity of oil palm plantations; second, construction of infrastructure that is adequate and must be related to the processing unit; third, development of research and development activities that have been less focused; fourth, discovering new technologies for product diversification; and fifth, there must be deregulation in the oil palm industry.

\section{CONCLUSION}

Plantation-based agricultural development aims to improve the lives of people so that there is a change in the pattern of life in the surrounding communities. On the other side, the success of oil palm agribusiness-based plantation development is expected to reduce income inequality among social groups and among regions.

The oil palm plantation activities are supported by146 units of oil palm mill (OPM) with a capacity of 6,254 tons per hour, which are scattered in different districts / cities in Riau Province. OPMs are not spread evenly, which are centered in the nucleus and plasma. Meanwhile, independent farmers' land lies far from the OPMs. This condition leads to low quality of FFB at the plants. Oil palm plantation cultivation in Riau evolves so rapidly, but it is not matched by the development of FFB processing industry construction called OPM. Lack of OPM processing capacity leads to accumulation of raw materials in the plantation sites.

Until 2011, oil palm plantation area reached $2,103,175$ ha with a production of $36,809,252$ tons 
of FFB. Meanwhile, the processing capacity of oil palm mill (OPM) only amounted to 30.0192 million tons. These conditions indicate the regional carrying capacity (RCC) of 1.584. Each FFB must be processed in less than 8 hours or RCC for OPM must be smaller than $1(\mathrm{RCC}<1)$. Riau region is still lack of 16 units of OPM with a capacity of 60 tons / hour or identical to 21 units with an OPM capacity of 45 tons / hour. OPM deficiency affects the price of oil palm and the income of farmers. On the other side, the high demand for OPM in Riau is a business opportunity for investors to develop OPM and industry of products derived from oil palm.

\section{Acknowledgement:}

The National Priority Research of Masterplan for Acceleration and Expansion of Indonesia's Economic Development in 20112025 (PENPRINAS MP3EI 2011-2025) is funded by the Directorate General of Higher Education of the Ministry of National Education for the fiscal year of 2013. The authors would like express gratitude to the Directorate of Research and Community Service through the Research Institute of the University of Riau which has provided opportunities and funding for the MP3EI research. Hopefully, the research findings would be instrumental to the development of science and the advancement of education in Indonesia.

\section{REFERENCES}

Almasdi Syahza., 2005. Dampak Pembangunan Perkebunan Kelapa Sawit Terhadap Multiplier Effect Ekonomi Pedesaan di Daerah Riau, in Jurnal Ekonomi, Th. X/03/November/2005, PPD\&I of Faculty of Economics, University of Tarumanagara, Jakarta.

-------., 2006. Studi Kelayakan Pengembangan Industri CPO dan Turunannya Di Kabupaten Bengkalis, Regional Planning Board of Bengkalis, Bengkalis

------., 2007a. Model Pemberdayaan Masyarakat dalam Upaya Percepatan Pembangunan Ekonomi Pedesaan Berbasis Agribisnis di Daerah Riau, Fundamental Research of Directorate of Research and Community Service (DP2M), Directorate General of Higher Education, Ministry of National Education, Jakarta.

-------., 2007b. Percepatan Pemberdayaan Ekonmomi Masyarakat Pedesaan dengan Model Agroestate Berbasis Kelapa Sawit, dalam Jurnal Ekonomi, Th.XII/02/Juli/2007, PPD\&I of Faculty of Economics, University of Tarumanagara, Jakarta.

------.., 2008. Percepatan Pembangunan Ekonomi Pedesaan Melalui Pemberdayaan Koperasi Berbasis Agribisnis Di Daerah Riau, Fundamental Research of Directorate of Research and Community Service (DP2M), Directorate General of Higher Education, Ministry of National Education, Jakarta.

------.., 2009a. Kelapa Sawit, Dampaknya Terhadap Percepatan Pembangunan Ekonomi Pedesaan di daerah Riau, Grant Research of Competence Year I, Directorate of Research and Community Service (DP2M), Directorate General of Higher Education, Ministry of National Education, Jakarta.

------.., 2009b. Perumusan Model Pengetasan Kemiskinan Melalui Pemetaan Kelembagaan Ekonomi Berbasis Agribisnis di Kabupaten Indragiri Hilir Provinsi Riau, National Strategic Research of Directorate of Research and Community Service (DP2M), Directorate General of Higher Education, Ministry of National Education, Jakarta.

-------., 2010. Kelapa Sawit, Dampaknya Terhadap Percepatan Pembangunan Ekonomi Pedesaan di daerah Riau, Grant Research of Competence Year II, Directorate of Research and Community Service (DP2M), Directorate General of Higher Education, Ministry of National Education, Jakarta.

-------., 2011. Kelapa Sawit, Dampaknya Terhadap Percepatan Pembangunan Ekonomi Pedesaan di daerah Riau, Grant Research of Competence Year III, Directorate of Research and Community Service (DP2M), Directorate General of Higher Education, Ministry of National Education, Jakarta.

., 2012. Pemberdayaan Ekonomi Daerah Melalui Penataan Kelembagaan dan Pengembangan Industri Hilir Berbasis Kelapa Sawit, Grant Research of Masterplan for Acceleration and Expansion of Indonesia's Economic Development (MP3EI) Year I, Directorate of Research and Community Service (DP2M), Directorate General of Higher Education, Ministry of National Education, Jakarta. 
Bustanul Arifin., 2001. Spektrum Kebijakan Pertanian Indonesia, Erlangga, Jakarta.

Dinas Perkebunan Propinsi Riau, 2011. Statistik Perkebunan, Riau Plantation Office, Pekanbaru.

Gumbira Sa'id, E. dan L. Febriyanti. 2005. Prospek dan Tantangan Agribisnis Indonesia. Economic Review Journal 200. (Online). www.bni.co.id/Document/16\%2520Agribisnis.pdf, Retrieved April 11, 2012.

Ginanjar Kartasasmita., 1996, Pembangunan untuk Rakyat, Memadukan Pertumbuhan dan Pemerataan, Cides, Jakarta.

Mustari. K. dan Mapangaja B., 2005. Analisis Daya Dukung Lingkungan untuk Melaksanakan Pembangunan Berkelanjutan di Kabupaten Gowa, in Jurnal Ecocelebica, Vo. 1 No. 2, January 2005, pp. 104-109.

Riau Terkini, 2006, Ke Depan Industri Sawit Menuju Industri Hilir, http://www.riauterkini.com/usaha.php?arr=9077. Retrieved March 12, 2012.

Otto Soemarwoto., 2001. Atur Diri Sendiri. Paradigma Baru Pengelolaan Lingkungan Hidup. Publisher: Gajah Mada University Press, Yogyakarta.

Todaro, Michael P., 2006. Pembangunan Ekonomi, Translated by Haris Munandar, Ninth Edition, Erlangga, Jakarta.

Yuswar Zainal Basri., 2003, Pemberdayaan Ekonomi Masyarakat Pedesaan, in Usahawan Indonesia No 03/TH.XXXII March 2003, Management Institute of Faculty of Economics, University of Indonesia, Jakarta. 